\title{
Avós e Netos na Literatura Infantil: vidas compartilhadas
}

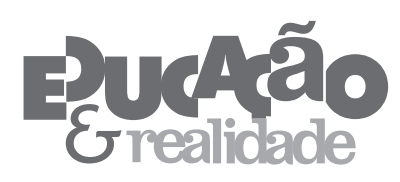

\author{
Célia Regina Delácio Fernandes' \\ 'Universidade Federal da Grande Dourados (UFGD), Dourados/MS - Brasil
}

RESUMO - Avós e Netos na Literatura Infantil: vidas compartilhadas. Este estudo aborda a representação de personagens velhas na literatura infantil do século XXI, com o foco na convivência entre avós e netos que, apesar das diferenças etárias, conseguem construir relações igualitárias. Para tanto, investiga em que medida as narrativas selecionadas recuperam as vozes, as histórias e os ensinamentos das personagens idosas, observando se as experiências desses sujeitos são valorizadas. Ao resgatar a função social do idoso nas narrativas infantis, por meio das lembranças e histórias contadas, o texto busca revelar as relações igualitárias entre avós e netos sem desconsiderar as diferenças, o que torna possível a coeducação de gerações e o aprendizado com a sabedoria descartada pela modernidade.

Palavras-chave: Velhos. Memória. Contar Histórias. Sabedoria. Coeducação de Gerações.

\begin{abstract}
Grandparents and Grandchildren in Children's Literature: shared lives. This paper approaches the representation of elderly people in children's literature of the 21st century, focusing on the experiences shared among grandparents and grandchildren and how they build equalitary relationships. It examines the voices, the stories and the teachings of elderly people in these narratives, observing whether these subjects' experiences are valued. In retrieving the social function of older people in children's narratives, by means of remembering and also by the stories told, this text aims to reveal equalitary relationships between grandparents and grandchildren, which points to the co-education of different generations and the learning processes involving knowledges discarded by modernity. Keywords: Elderly People. Memory. Story Telling. Knowledge. Co-education of Generations.
\end{abstract}

Educação \& Realidade, Porto Alegre, v. 38, n. 4, p. 1089-1112, out./dez. 2013. 1089 Disponível em: <http://www.ufrgs.br/edu_realidade> 


\title{
Algumas Palavras sobre a Velhice, a Memória e o Contar Histórias
}

"Os idosos são os que contam melhor, pois já escutaram mais" (Provérbio tradicional).

O tema da representação da velhice na literatura infantil do século XXI, focado na vida cotidiana de avós e netos, foi escolhido, tendo em vista a importância da discussão sobre a posição social do idoso na sociedade atual, bem como a quase ausência de pesquisas sobre esse assunto tanto na área da educação quanto da literatura.

A preocupação com a velhice não é tema atual; ela não nasceu com o advento da geriatria. Na Grécia Antiga, Hipócrates “[...] foi o primeiro a estabelecer um paralelo entre as etapas da vida humana e as quatro estações da natureza, comparando a velhice com o inverno" (Beauvoir, 1976, p. 19) e, após ele, muitos filósofos e literatos se preocuparam com a velhice, engrandecendo-a ou ridicularizando-a.

É comum escutar notícias do bom padrão de vida que levam os europeus, inclusive quando se aposentam. Assim, imagina-se que a sociedade lhes garanta uma velhice tranquila e confortável. A boa imagem construída a respeito do envelhecimento na Europa no século XX, no entanto, pode ser contraposta às denúncias feitas por Simone de Beauvoir (1976), resultantes de uma instigante e exaustiva pesquisa sobre a velhice, tendo como objetivo principal demonstrar o destino das pessoas idosas no mundo contemporâneo:

\begin{abstract}
[...] o fato de ser um homem reduzido à condição de "sobra", de resto, durante os últimos quinze ou vinte anos de sua existência, comprova a falência de nossa civilização; semelhante evidência nos deixaria interditos se considerássemos os velhos como seres humanos, tendo às suas costas uma existência humana e não como cadáveres ambulantes... (Beauvoir, 1976, p. 11).
\end{abstract}

Beauvoir (1976) examinou o conceito de velhice no campo da biologia, antropologia, história, sociologia e literatura, e afirmou que nenhuma dessas áreas define a velhice, pois esta assume múltiplos aspectos, sendo difícil delimitá-la. A autora a entende como um processo multifacetado da vida humana:

\begin{abstract}
[...] um fenômeno biológico: o organismo do homem idoso apresenta certas singularidades. Acarreta consequências psicológicas: determinadas condutas, com justa razão, são consideradas típicas da idade avançada. Tem uma dimensão existencial como todas as situações humanas: modifica a relação do homem no tempo e, portanto, seu relacionamento com o mundo e com sua própria história. Por outro lado, o homem nunca vive em estado natural: seu estatuto lhe é imposto, tanto na velhice como em todas as idades, pela sociedade a que pertence (Beauvoir, 1976, p. 13).
\end{abstract}

1090 Educação \& Realidade, Porto Alegre, v. 38, n. 4, p. 1089-1112, out./dez. 2013 Disponível em: <http://www.ufrgs.br/edu_realidade> 
Embora muito se tenha feito no sentido da preservação da juventude, não há nada que se possa fazer para evitar o fenômeno biológico do envelhecimento a que todos nós estamos fadados, e muitos dizem preferir a morte a chegar a esse estado. Simone vai além em seu estudo sobre a velhice, questionando diversas sociedades, desde as mais primitivas, sobre o tratamento para com os idosos, e nota que, se nem o direito a viver livremente o homem tem, quanto mais a envelhecer. Para ela, o idoso só será acolhido como ser humano a partir do momento em que determinada sociedade passar a tratar o homem enquanto homem. Ao analisar a condição dos velhos no decorrer do tempo, Beauvoir aponta que a maior contribuição deles para as sociedades são a memória e a experiência, transmitidas oralmente.

No Brasil, as indagações a respeito da velhice também têm sido formuladas. Numa obra densa, sensível e comovente, Memória e Sociedade: lembranças de velhos, Ecléa Bosi (1987) fala da recusa do idoso em estar abandonado, demonstrando que a função social da velhice é a de lembrar. O idoso lembra e aconselha, unindo o início ao fim por meio da memória, que é uma forma de ele trabalhar, sendo que já trabalhou por nós nessa sociedade e quer continuar contribuindo para melhorar o futuro com suas experiências vividas. Ela reflete sobre a destruição sistemática que os homens sofrem na sociedade industrial, onde ser velho é lutar para sobreviver. É importante ressaltar que a representação do velho sofre mudanças em diversas sociedades e ao longo do tempo, resultando da construção de valores e crenças de cada sociedade:

\begin{abstract}
Ele, nas tribos antigas, tem um lugar de honra como guardião do tesouro espiritual da comunidade, a tradição. Não porque tenha uma especial capacidade para isso: é seu interesse que se volta para o passado que ele procura interrogar cada vez mais, ressuscitar detalhes, discutir motivos, confrontar com a opinião de amigos, ou com velhos jornais e cartas em nosso meio (Bosi, 1987, p. 40).
\end{abstract}

Nas sociedades capitalistas, novos hábitos foram se formando para adaptar o ritmo humano à medida do relógio, impondo-se uma nova disciplina de trabalho e esvaziando o seu tempo de experiências significativas. Nesse contexto, em que a racionalização surge como um aperfeiçoamento da produção e os números valem mais do que qualquer vida humana, não há mais lugar para a lentidão do velho, e ele é empurrado para a margem. Em contraposição, Ecléa Bosi, assim como Simone de Beauvoir, identifica uma dimensão importante na concepção de velhice quando constata o sentido da existência da velhice na memória: “[...] o vínculo com outra época, a consciência de ter suportado, compreendido muita coisa, traz para o ancião alegria e uma ocasião de mostrar sua competência. Sua vida ganha uma finalidade se encontrar ouvidos atentos, ressonância” (Bosi, 1987, p. 40).

Na esteira desses estudos, a jovem pesquisadora Célia Regina Delácio, no texto Os Idosos e o Tempo Útil de Trabalho (1988), relaciona o

Educação \& Realidade, Porto Alegre, v. 38, n. 4, p. 1089-1112, out./dez. 2013. 1091 Disponível em: <http://www.ufrgs.br/edu_realidade> 
Avós e Netos na Literatura Infantil

problema dos idosos em nossa sociedade com a ideia de tempo útil de trabalho, pois, enquanto o homem está em condições para produzir, ele ainda consegue se garantir; quando isso deixa de acontecer, passa a ser sobrevivente, excluído por não oferecer lucros, como no caso de idosos pobres que foram entrevistados na cidade de Marília, interior de São Paulo. Célia, inspirada pelas leituras realizadas na disciplina de Sociologia I, ministrada pelo professor Paulo de Salles Oliveira, em 1988, no curso de Filosofia da Universidade Estadual Paulista (UNESP), almeja recuperar as vozes, os ensinamentos e os projetos desses sujeitos: “[...] procura construir um conhecimento que não separa a teoria da prática e, ao estabelecer um consórcio com a Literatura, não o faz com o intuito de emoldurar e sim de complementar, articuladamente, os fundamentos da teoria social" (Oliveira, 1988, p. 4-5).

Também Paulo de Salles Oliveira (1999), numa reflexão interdisciplinar, debruçou-se sobre a velhice, com o foco na vida cotidiana de avós e netos que moram em bairros pobres na cidade de Marília, estado de São Paulo, entrevistando sujeitos que vivem a dupla opressão, como integrantes de uma classe social e de um grupo etário. A despeito disso, esse arguto e sensível pesquisador encontrou nesses sujeitos diferentes a concretização de relações igualitárias de convivência, desvelando a capacidade dessas pessoas em construir uma cultura original, que resiste à massificação e às relações de consumo. Ao partilharem suas vidas, com laços estreitos enraizados na cultura, avós e netos se influenciam e se modificam reciprocamente, tornando possível uma coeducação de gerações: "Os avós educam, portanto, os netos e, ao mesmo tempo, embora de modo diferente, são reeducados por essas crianças" (Oliveira, 1999, p. 24).

Essa socialização do saber na convivência entre avós e netos, com a troca de experiências e a nutrição mútua da cultura oral, pode ser compreendida, de acordo com Oliveira (1999), como contraponto ao desdobramento da barbárie, previsto por Walter Benjamin com o definhamento da arte de narrar, porque fundamentada no ato de conversar: "Com os avós, o ritmo é outro. As lembranças, banhadas pela experiência devida e pelo afeto, recompõem a arte de contar, uma prosa que não conhece cronômetro. [...]" (Oliveira, 1999, p. 21).

Nesse sentido, pode-se dizer que o velho, assim como o narrador, “[...] é um homem que sabe dar conselhos" (Benjamin, 1987, p. 200). O filósofo ainda revela que "[...] o narrador retira da experiência o que conta: sua própria experiência ou a relatada pelos outros. E incorpora as coisas narradas à experiência de seus ouvintes" (Benjamin, 1987, p. 205). Para que não se interrompa a arte de contar histórias, é preciso que haja ouvintes para "[...] contá-las de novo, e ela se perde quando as histórias não são mais conservadas. Ela se perde porque ninguém mais fia ou tece enquanto ouve a história" (Benjamin, 1987, p. 205).

Como se sabe, a literatura infantil tem sua origem nas narrativas orais que circulavam de boca em boca, transmitidas de geração para

1092 Educação \& Realidade, Porto Alegre, v. 38, n. 4, p. 1089-1112, out./dez. 2013 Disponível em: <http://www.ufrgs.br/edu_realidade> 
geração, ultrapassando fronteiras de tempo, espaço, língua e idade. Um dia essas histórias foram escritas em livro e continuaram a perambular pelo mundo. Registra-se que as primeiras obras para crianças foram produzidas no final do século XVII, na França, recebendo a herança da tradição popular: “As Fábulas (1668) de La Fontaine, os Contos da Mãe Gansa (1691/1697) de Charles Perrault, os Contos de Fadas (8 vols. 1696/1699) de Mme. D’Aulnoy e Telêmaco (1699) de Fénelon” (Coelho, 1991, p. 75).

Em terras brasileiras, a literatura infantil surge cem anos depois, no final do século XIX, por meio de traduções e adaptações das histórias infantis europeias. Segundo Zilberman (2005), os escritores brasileiros repetiram o percurso ocorrido na Europa, alimentando-se das narrativas transmitidas oralmente, como, por exemplo, um de seus pioneiros, Figueiredo Pimentel (1869-1914):

\begin{abstract}
[...] Quando decidiu dedicar-se à literatura infantil, preferiu seguir o caminho sugerido pelos irmãos Grimm. Publicou coletâneas de muito sucesso, como os Contos da Carochinha (1984), onde se encontram as histórias de fadas europeias, ao lado de narrativas coletadas entre os descendentes dos povoadores do Brasil. Há histórias de origem portuguesa e também narrativas contadas pelas escravas que educavam a infância brasileira no século XIX. Foi como a tradição popular e oral entrou na literatura infantil brasileira, para não mais sair (Zilberman, 2005, p. 17-18).
\end{abstract}

Outro importante trabalho, pioneiro na formação do campo da crítica literária sobre o gênero no Brasil, da educadora e escritora Cecília Meireles, Problemas da Literatura Infantil, reconhece a relevância da arte de contar histórias ao longo do tempo e vê sua permanência na literatura infantil como um legado da literatura tradicional:

O ofício de contar histórias é remoto. Em todas as partes do mundo o encontramos: já os profetas o mencionam. E por ele se perpetua a literatura oral, comunicando de indivíduo a indivíduo e de povo a povo o que os homens, através das idades, têm selecionado da sua experiência como mais indispensável à vida.

[...] não se pode deixar de sentir uma profunda admiração por esses narradores anônimos que com a disciplina da sua memória e da sua palavra salvaram do esquecimento uma boa parte da educação da humanidade (Meireles, 1979, p. 41).

Com efeito, a presença da narrativa oral na literatura infantil é evidenciada, principalmente, em alguns escritores que trazem as vozes dos contadores de histórias, conferindo-lhes o papel de narradores. Marisa Lajolo e Regina Zilberman mostram essa ocorrência na literatura infantil brasileira escrita entre 1920 e 1945:

Educação \& Realidade, Porto Alegre, v. 38, n. 4, p. 1089-1112, out./dez. 2013. 1093 Disponível em: <http://www.ufrgs.br/edu_realidade> 
Igualmente características desse período são histórias de origem folclórica, narradas por uma negra (doméstica e/ ou ex-escrava) a crianças atentas. Resultam da transposição literária de um hábito tradicional da educação brasileira, quando esta não era administrada apenas pela escola. Viriato Corrêa descreve o tipo em Cazuza (v. A contadeira de histórias), no que fora antecipado por José Lins do Rego (v. Aos meninos do Brasil), com as Histórias da Velha Totônia. Seguindo a moda, mas adotando postura iconoclasta perante os valores da cultura popular, Monteiro Lobato promove a cozinheira do sítio a narradora titular em Histórias da Tia Nastácia (Lajolo; Zilberman, 1986, p. $65)$.

Em outra obra, essas autoras assinalam que foi comum a migração do contador de histórias, figura assídua na vida de sociedades escravocratas, para o interior das páginas da literatura infantil, durante certa fase da produção de livros para as crianças, como modelo de transmissão de histórias - segundo elas, o mesmo modelo proposto por Walter Benjamin - para uma cultura que ainda não tinha muita proximidade com o mundo da leitura:

O modelo de Monteiro Lobato é exemplar: tratava-se de aproveitar um processo de narrativa oral, encampando e transferindo para a literatura a figura que fazia o papel de transmissora da tradição folclórica. Desse modo, a obra de Lobato parece sugerir um percurso interessante para a formação de leitores: rejeita as experiências mais ortodoxas de leitura e recorre à sua origem mais primitiva, a narração e a audição oral, quando contador e ouvintes - a plateia atenta, silenciosa e, quando necessário, também participante - partilham espaço e tempo [...] (Lajolo; Zilberman, 1998, p. 217).

Além da personagem Tia Nastácia, é preciso destacar o importante papel de outra velha senhora na obra de Lobato: Dona Benta, avó de Narizinho e Pedrinho, que dirige o Sítio do Pica-Pau Amarelo por meio do convívio democrático entre as pessoas. Dona Benta conta histórias para os netos e possibilita a participação dos ouvintes, incentivando-os a criarem novas histórias a partir da história narrada. Após esse período, as marcas da oralidade continuaram presentes no gênero. No entanto, parece ter ocorrido um certo apagamento da personagem idosa na literatura infantil. De acordo com Alice Martha (2004, p. 84), num dos raros estudos encontrados sobre o tema em questão, o desaparecimento da imagem do velho na literatura infantil contemporânea estaria explicado pela ideia de que "[...] aos leitores jovens só interessam personagens crianças e adolescentes”. Desse modo, complementa a autora, "[...] o apagamento da personagem idosa, naturalmente, pode estar relacionado à visão negativa da velhice como transformação efetuada pelo tempo, quando se pensa na degradação dela resultante [...]" (Martha, 2004, p. 84).

1094 Educação \& Realidade, Porto Alegre, v. 38, n. 4, p. 1089-1112, out./dez. 2013 Disponível em: <http://www.ufrgs.br/edu_realidade> 
Em vista do exposto, e considerando o poder das palavras para reforçar ou transformar determinadas concepções de mundo de grupos dominantes, este artigo pretende estudar as representações de personagens velhas em dez obras contemporâneas produzidas para o público de menor idade, observando em que medida as narrativas selecionadas recuperam as vozes, as histórias e os ensinamentos das personagens avós que convivem com os netos.

Em conjunto com as valiosas reflexões de Ecléa Bosi (1987), Simone Beauvoir (1976), Paulo de Salles Oliveira (1999) e Walter Benjamin (1987), que fundamentam este trabalho, acredita-se ser possível compreender as imagens que os escritores construíram sobre a velhice, com o foco na representação de avós, na literatura infantil do século XXI que circula no Brasil. Ao fazê-lo, talvez se possam enunciar em bases mais sólidas a compreensão e a redefinição desse processo complexo e multifacetado da vida humana, contribuindo para refletir e recriar relações mais igualitárias entre sujeitos de diferentes gerações, com reconhecimento e respeito pela alteridade, na humanização do ser humano e da sociedade.

\title{
Histórias, Saberes, Troca de Experiências e Afetos na Convivência entre Avós e Netos
}

\author{
E assim como às vezes a gente pára pra ver uma estrela \\ ou um pássaro, alguns netos param e ouvem essa música \\ secreta que sai de dentro dos avós. Eles viveram uma vida \\ inteira... e quantas malas e armários poderiam encher \\ com suas aventuras? (Murray, 2000, p. 8).
}

As dez obras literárias infantis selecionadas para este estudo têm em comum o fato de mostrar representações de velhos que contracenam com crianças, ou seja, as narrativas colocam em foco dois extremos etários de uma família para conviverem: avós e netos. O estudo dessas obras aponta para um convívio igualitário em que ambos reconhecem seu interlocutor como pessoa: as crianças trazem esperança, ânimo e alento para os velhos, enquanto esses criam outras perspectivas para a vida dos pequenos na partilha de suas experiências, histórias e lembranças. Nessas vidas compartilhadas, a relação entre avós e netos sofre influências e modificações recíprocas, constituindo-se um processo de coeducação de gerações (Oliveira, 1999), como se pode perceber ao longo deste artigo.

Na obra Álbum de Família (Albergaria, 2005), narrada em primeira pessoa pela ótica da criança, a vida da menina Manuela é enriquecida com histórias de antigamente, primeiro com a chegada da bisavó (avó da mãe), que veio morar em sua casa, e depois com a vinda de seu bisavô (avô do pai).

A bisavó, chamada pela narradora protagonista de vovó, muda do Rio de Janeiro para uma cidade pequena e traz consigo, além da mala-

Educação \& Realidade, Porto Alegre, v. 38, n. 4, p. 1089-1112, out./dez. 2013. 1095 Disponível em: <http://www.ufrgs.br/edu_realidade> 
sanfona que transporta suas roupas, um baú de recordações - enxoval e retratos - e uma caixa redonda de guardar chapéu, que preservam os objetos selecionados pela sua memória e resgatam sua história de vida. Junto com a sua própria história, essa memória reconstitui o retrato de um tempo, a história do passado de uma cidade e de seus costumes, que é compartilhada com outra geração:

\begin{abstract}
Vovó morava havia muito tempo no Rio, desde que lá era a capital do Brasil. Desde a época dos bondes, dos homens de chapéu, das mulheres de chapéu. A caixa era daquela época. Homens e mulheres usavam chapéu sempre que saiam de casa. Iam ao cinema de chapéu. Às corridas de cavalos, aos passeios pela cidade. Naquele tempo, o povo andava despreocupadamente pelas ruas e cuidava muito das roupas. Os homens sempre de gravata. As mulheres, que não gostavam de sol, abriam a sombrinha.

Era vovó me explicando como os cariocas viviam (Albergaria, 2005, p. 13).
\end{abstract}

Se, por um lado, essa convivência cotidiana é partilhada afetuosamente com a neta Manuela, por outro lado, ela é conflituosa com o pai da menina que vê o baú como algo que ocupa lugar e atravanca a passagem para a sala, e ainda por conta do álbum de fotografias que influencia a filha a colecionar figurinhas. Em resumo, o pai vê a presença da avó na casa como um estorvo, porque em sua visão ela não produz nada de útil:

Papai implicava com a vovó. Porque ela nunca ajudava mamãe. Porque o baú dela não cabia no quarto e ficava atravancando a sala. Porque vovó comprou um álbum de fotografias e ficava toda a vida colocando nele aqueles retratos que tirava do baú (Albergaria, 2005, p. 18).

E porque eu ficava ao lado da vovó, de repente com a mania de pregar figurinhas num álbum e também pedindo dinheiro à mamãe para ir com a vovó comprar mais figurinhas no jornaleiro.

- Só falta essa menina pintar o cabelo de azul! - papai resmungava, quando vovó não podia ouvir (p. 20).

- Por que é que a sua avó não faz crochê nem goiabada? Pelo menos fazia alguma coisa útil. Não sei como não engorda de tanto ficar à toa - era papai outra vez (Albergaria, 2005, p. 21).

Passado alguns meses, o avô do pai de Manuela também vem morar na casa trazendo uma mala média com dois chapéus e uma caixinha de rapé. O avô Neném (avô do pai) veio morar na casa porque perdeu as forças para realizar o trabalho árduo da roça:

Vovô ria muito. Quando resolveu vender o sítio que tinha, disse que estava cansado de trabalhar na roça. E que estava alegre por ter vindo viver um pouco na cidade. Ele deu adeus à casa com o pomar, aos pés de milho e de feijão, ao

1096 Educação \& Realidade, Porto Alegre, v. 38, n. 4, p. 1089-1112, out./dez. 2013. Disponível em: <http://www.ufrgs.br/edu_realidade> 
moinho d’água, aos cavalinhos e aos cabritos. Tudo agora era de outro dono (Albergaria, 2005, p. 28).

A convivência com o avô é permeada de conflitos com a mãe de Manuela, que reclama do cheiro do cigarro de palha e o proíbe de "[...] pitar dentro de casa” (Albergaria, 2005, p. 34); em outro episódio, o motivo é porque ele inventa de fazer um galinheiro junto com a menina no quintal de sua casa: “- O danado do seu Neném sabia que eu queria fazer um jardim no quintal, Antônio!” (Albergaria, 2005, p. 40). Em compensação, a relação dele com a neta é repleta de invenções, cumplicidades e aprendizagens:

Apesar de gordo, vovô não aguentava ficar quieto como a vovó. Por isso, um dia resolveu que ele e eu íamos criar galinhas. Cercou o quintal com uma tela, bateu estacas no chão para prender a tela, fez um poleiro de madeira, fez ninhos de caixote para a galinhada botar e chocar. Quando nasceram os primeiros pintinhos, achei a coisa mais linda, com aquela penugem amarela, quase tão redondos quanto o vovô. Pena que cresciam e emagreciam quando viravam frangos (Albergaria, 2005, p. 38).

Observa-se uma dimensão lúdica na vida cotidiana entre avô e neta (Oliveira, 1999), nas relações com os animais e com a natureza: "Eu adorava dar milho às galinhas junto com vovô” (Albergaria, 2005, p. 40). A aprendizagem não dissocia o saber e o fazer também presentes na construção de um banco e na arte de contar histórias. Ele contava histórias para a menina apenas quando chegava a noite, porque segundo sua crença na sabedoria popular: "História, Manuela, só tem graça de noite. Quem conta história de dia cria rabo de cutia!” (Albergaria, 2005, p. 34):

Comecei a esperar que ficasse de noite. Meu coração até batia mais alegre. Quando chegava a noite, nem ligava mais a televisão. Vovô me levava para o quintal, e nós dois ficávamos ao lado um do outro num banquinho que ele mesmo fez, logo nos dois em que chegou. Então, vovô me contava histórias (Albergaria, 2005, p. 32).

Na roça também era costume as pessoas sentarem na varanda e ouvirem histórias até o sono chegar. Esse hábito rural é inserido no cotidiano urbano da neta:

No joelho do vovô, abraçada com a barriga redonda dele, eu ouvia as aventuras de um burrinho encantado. Ele tinha ferraduras mágicas, e, por isso, seu galope podia se transformar em um voo. A Lua era sua madrinha, e ela mesma tinha feito as ferraduras da cor dos seus raios. Ela sempre protegia o afilhado, iluminando o caminho para o burrinho fugir de seus inimigos.

Em cada história, o burrinho tinha um dono diferente, dono bom ou ruim, gente grande ou menino, mas quase nunca eu ouvia o fim da história. Quase sempre dormia

Educação \& Realidade, Porto Alegre, v. 38, n. 4, p. 1089-1112, out./dez. 2013.1097 Disponível em: <http://www.ufrgs.br/edu_realidade> 
no colo do vovô, escutando o burrinho trotar, vendo o brilho da sua ferradura de prata levantando poeira pela estrada... (Albergaria, 2005, p. 36)

Outra observação digna de nota é a questão da sexualidade na terceira idade que é encenada no final da história. Álbum de Família não apenas dá vozes aos velhos, mas também aponta para seus projetos de vida, para inusitadas possibilidades de amor nessa fase da vida. Na história, é a criança a mediadora de uma relação amorosa entre dois velhos viúvos. Os pais vão para uma festa na cidade e a menina aproveita a ausência deles e resolve fazer uma festa junto com seus avós, que a partir daí começam a namorar e depois vão viver juntos numa casa construída no quintal:

A casinha que vovô começou a construir no quintal foi ficando do jeito que vovó queria. As janelas tinham jardineiras do lado de fora. Do lado de dentro, cortinas de renda. O baú ficou bem no meio da sala nova, coberto por uma toalha bordada. Num porta-retrato, uma foto novinha. A minha (Albergaria, 2005, p. 52).

Já a valorização da arte de contar histórias está presente de forma muito singela, lírica e encantadora em Um Avô e seu Neto, de Roseana Murray (2000), revelando a sabedoria dos avós por guardarem a infância deles na memória, como guardiões que preservam tesouros de um mundo que já não existe mais:

Esta é uma história muito simples. Fala do amor entre um avô e seu neto, que é como a magia que existe entre a noite e a lua. Os avós sabem de muitas coisas. Os avós guardam a infância deles na memória, com seus rios azuis, suas ruas de barro, chapéus, cavalos, lampiões. Um mundo tão antigo que já quase não cabe mais neste mundo (Murray, 2000, p. 5).

Em vista disso, eles precisam lembrar e deixar esse legado para os netos compartilharem com as gerações futuras. O narrador, em terceira pessoa, dá voz a um eu que interfere na narrativa e evidencia seu ponto de vista:

Quando um avô morre, esse mundo antigo morre com ele, assim como todos os cavalos, rios azuis, ruas de barro. Por isso eu, particularmente, acho que os avós nunca deveriam morrer. Mas, para que as coisas que eles guardam lá no fundo deles - essa poeira encantada de outros tempos - não desapareçam completamente, existem os netos (Murray, 2000, p. 6).

A narrativa sinaliza que a exclusão do velho no mercado de trabalho, depois de uma vida inteira de labuta, retira a alegria do viver do avô, porque ele parou de produzir:

1098 Educação \& Realidade, Porto Alegre, v. 38, n. 4, p. 1089-1112, out./dez. 2013. Disponível em: <http://www.ufrgs.br/edu_realidade> 
O avô tinha a barriga grande. O neto achava que havia um sol lá dentro, ou uma fábrica de alegria. O avô ria tanto! Mas um dia o avô parou de trabalhar. Era como se a barriga tivesse diminuído, ou uma nuvem tivesse escondido o sol. O neto passava a mão nos cabelos do peito do avô. Os avós são tão lindos com seus cabelos brancos... (Murray, 2000, p. 10).

Observa-se que a felicidade do avô depende do reconhecimento do outro. Em uma sociedade que valoriza apenas aqueles que produzem riquezas materiais, o avô precisa relembrar que já produziu. A memória do trabalho devolve sua dignidade. Chama a atenção a escuta do neto, ouvinte atento que acompanha suas histórias:

Quando o avô estava feliz, contava histórias malucas: de elefantes cantores de ópera, de crocodilos vendedores. Mas, quando se lembrava que não podia mais trabalhar, que se não fizesse bastante barulho ninguém se lembraria mais dele, aí só contava histórias da sua vida. (O neto ouvia.) (Murray, 2000, p. 12).

[...] E voltava a contar histórias malucas, sem pé nem cabeça, de bichos fantásticos. Sua barriga novamente engolira o sol (Murray, 2000, p. 28).

Como se vê, Um Avô e seu Neto traz a delicadeza do convívio entre os avós e netos, com a partilha de uma outra história que o avô conta e o neto a ouve atentamente, saboreando suas palavras e aprendendo com suas experiências.

De fato, a função do idoso é lembrar, recuperar o passado por meio da memória (Bosi, 1987). Nesse prisma, a obra A Colcha de Retalhos, de Conceil Corrêa da Silva e Nye Ribeiro (2010), narra em terceira pessoa a história de um menino e sua avó que juntos fazem uma colcha, por meio da costura de retalhos que registram pedaços da memória da família, guardada como um tesouro.

Felipe passa os finais de semana na casa da avó, que sabe fazer comidas, bolos e doces deliciosos, tudo aquilo de que ele gosta, e não coloca horário para as coisas. A arte de contar histórias está presente na magia da relação entre avós e netos:

Vovó sabe contar histórias como ninguém.

- Conta mais uma, vovó. Só mais uma!

Vovó coloca os óculos bem na ponta do nariz, faz cara engraçada e fala bem fininho e fraquinho, imitando a voz da Chapeuzinho Vermelho, e bem grosso e forte, imitando a voz do lobo mau. Ah! Quem é que não gosta de uma vovozinha assim? (Silva; Ribeiro, 2010, p. 6).

Nessa narrativa, a criação de uma colcha de retalhos simboliza a recuperação da memória das histórias da família $\mathrm{O}$ menino ajuda a avó a fazer uma colcha com os pedaços de panos que sobraram das costuras que a avó juntou ao longo de sua vida, separando os retalhos um a um. Cada retalho evoca uma história; Felipe lembra alguns que fizeram

Educação \& Realidade, Porto Alegre, v. 38, n. 4, p. 1089-1112, out./dez. 2013. 1099 Disponível em: <http://www.ufrgs.br/edu_realidade> 
parte de sua existência e ela complementa; além disso, recorda outros momentos de um passado não vivenciado por ele.

\begin{abstract}
- Olha esse pano listrado, é daquele pijama que você fez para mim quando a gente passou aqueles dias no sítio, lembra?

- É mesmo, Felipe, estou me lembrando. Que férias gostosas! Andamos a cavalo, chupamos jabuticaba... As jabuticabeiras estavam carregadinhas (Silva; Ribeiro, 2010, p. 11).
\end{abstract}

Assim, avó e neto vão cosendo os retalhos que juntos compõem a história da família. Destaca-se que, sem subestimar a capacidade da criança, o tema da morte - e também da saudade - aparece em meio às lembranças:

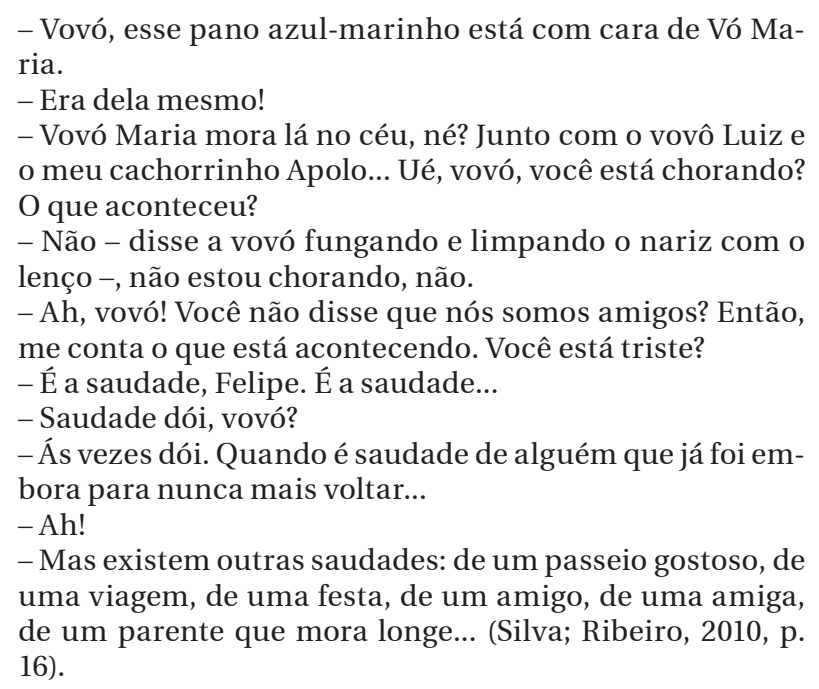

Apesar da pouca idade, Felipe compreende o sentimento da saudade vivenciando-o na ausência temporária da avó: "Sabe, vovó... - cochichou Felipe, bem baixinho, no seu ouvido -, preciso te contar um segredo: eu acho que já entendi...agora eu já sei o que é saudade!" (Silva; Ribeiro, 2010, p. 23). Por fim, o menino ganha a colcha de retalhos de presente da avó, uma colcha muito diferente dessas "[...] que se vendem nas lojas" (Silva; Ribeiro, 2010, p. 19). Um lindo trabalho manual que resiste às práticas de consumo das sociedades modernas, que descartam as coisas velhas em função das novidades (Oliveira, 1999). A criação da colcha é uma recriação da vida conjunta, um grande aprendizado para ambos.

Também nessa perspectiva, a obra A Manta: uma história em quadrinhos (de tecido), Isabel Minhós Martins (2011) começa falando da herança maior deixada pela avó: a manta que contava histórias. A história é narrada pela neta, após a morte da avó, que dormia numa cama grande e usava uma manta para contar histórias:

1100 Educação \& Realidade, Porto Alegre, v. 38, n. 4, p. 1089-1112, out./dez. 2013 Disponível em: <http://www.ufrgs.br/edu_realidade> 
A princípio, estranhávamos o colchão duro e os cobertores pesados, mas, passados alguns minutos, não havia no mundo melhor lugar para adormecer.

A minha avó nos aquecia os pés e nos contava histórias antigas até o sono nos vencer.

Não contava histórias de um livro porque não precisava.

Tínhamos a manta (Martins, 2011, p. 5, grifo da autora).

O registro é oral e feito por meio de cada retalho, sobra de algo que foi guardado, prática avessa ao consumismo tão presente na vida atual, e que acena para resistência e outras maneiras de reinventar o mundo:

A manta era enorme, feita de centenas de pequenos retalhos.

Cada retalho, uma história.

Quando apontávamos um retalho, vovó dizia sempre:

- Ah, esse não tem nada para contar...

Mas depois começava. E a viagem era sempre emocionante (Martins, 2011, p. 8, grifo da autora).

A manta possibilita uma forma de aprendizagem que não dissocia o saber do fazer e é reconhecida pela família como o mais valioso legado deixado pela geração mais velha. Convém frisar que o bem mais disputado entre as filhas, após a partida da mãe, é a manta:

Quando a minha avó morreu, todas as minhas tias queriam a manta, mais valiosa que todo o resto. Emburraram durante uns dias, mas depois lá se entenderam porque sempre foram amigas. Desde então, ficou combinado que a manta fica um mês na casa de cada uma.

Nos meses em que está aqui, vem cobrir a minha cama, e é como se eu voltasse a estar com minha avó e com todas as suas histórias (Martins, 2011, p. 19).

Com o passar do tempo, no final da narrativa, alguns retalhos precisam ser substituídos por outros, apontando para a ideia de continuidade das outras gerações: "Eu e a minha avó, as duas dormindo lado a lado, até os tecidos se gastarem e novas histórias chegarem a esta manta" (Martins, 2011, p.23).

Com menos densidade e uma visão idealizada da relação entre a avó e a neta, Casa de Vó é Gostoso que Só, de Magali Queiroz (2010), mostra o espaço da casa da avó como o lugar de boas lembranças, onde a neta Yasmin ganha colo, escuta histórias, come guloseimas e brinca com os amigos sem nenhuma preocupação. Espaço de convivência entre gerações diferentes sem conflitos e de muitas aprendizagens. Lugar idílico no campo, que se assemelha a um parque de diversões, lugar de aventuras, onde se estabelece uma relação dialógica, sem a presença castradora dos pais. Depois de um dia cheio de brincadeiras, a avó conta histórias para a neta adormecer: "A lua já está pendurada lá no céu. Vovó faz um lanche gostoso e conta histórias até o sono chegar” (Queiroz, 2010, p. 7).

Educação \& Realidade, Porto Alegre, v. 38, n. 4, p. 1089-1112, out./dez. 2013.1101 Disponível em: <http://www.ufrgs.br/edu_realidade> 
Avós e Netos na Literatura Infantil

Certamente, a presença da dimensão lúdica na vida compartilhada entre a avó e a neta pode ser percebida nas brincadeiras, nas histórias e nas relações com os animais e com a natureza. Nos trechos selecionados a seguir, visualiza-se o aprendizado da vida cotidiana do campo, em comunhão com a natureza, e do trabalho coletivo:

Vovó e Yasmin colocam o novo amigo em um velho ninho, no vaso da samambaia, a planta comprida pendurada na varanda (p. 16).

Quando o passarinho fica mais forte, voa bem alto e desaparece no céu (p. 17).

Na casa da vó tem muitas coisas para fazer.

Quando os amigos chegam, o sol ainda está muito quente. Então, todo mundo vai limpar as folhas que caem da parreira.

Enquanto a vovó varre, as crianças ajudam.

- E se todos ajudam, ninguém se cansa - vovó ensina (Queiroz, 2010, p. 18-19).

De um ângulo mais denso, criativo e envolvente, Avó com Cheiro de Pão Caseiro, de Zé Zuca (2010), narra, pela ótica de um menino de onze anos, as lembranças e os sabores da infância de Lúcio, que foi criado junto por sua avó Belinha e nutre um afeto muito grande por ela. $\mathrm{Na}$ descrição da avó, o narrador protagonista revela a solidão da velhice e o preenchimento desse vazio na convivência amorosa com o neto:

Uma mulher solitária. Dedicada à nossa família. Assumia as tarefas da casa durante a semana. Meu pai viajava muito e nunca curtiu a mãe que tem. Eu é que sempre ganhei os carinhos dela. Acho que conheço melhor do que ele, talvez por ser filho único. Como minha mãe trabalhava durante o dia, foi minha avó quem cuidou de mim a maior parte do tempo.

Vovó era uma mulher tão sozinha que dava pena. Eu tentava preencher todo aquele espaço vazio.

Acho que ninguém cozinha como minha avó. Ela vive juntando receitas. E confesso que, além de ser a pessoa que mais amo nesse mundo, ela sempre me pegou também pelo estômago. Adoro aquele frango com batatas que ela faz, as panquecas de vários sabores, os sorvetes de frutas e creme... Que delícia!

Ela era fofinha, cabelos meio castanhos, meio brancos. Um rosto de anjo amadurecido. Com sua fala mansa me contava histórias de fadas e gigantes. Eu sempre amei minha avó (Zuca, 2010, p. 6).

A morte do marido, seguida do abandono e solidão, esvazia a vida da avó Belinha, que primeiro encontra ânimo para viver ocupando-se do neto e, mais adiante, apaixona-se pelo Seu Manu, o padeiro, e os dois namoram escondidos até serem flagrados pelo menino: "Fiquei lá, olhando pro teto escandalizado. Como é que aminha avó, logo a minha, com aquela idade, ia ficar namorando feito uma adolescente?" (Zuca, 2010, p. 11).

1102 Educação \& Realidade, Porto Alegre, v. 38, n. 4, p. 1089-1112, out./dez. 2013 Disponível em: <http://www.ufrgs.br/edu_realidade> 
A narrativa aborda o tema da sexualidade do idoso de forma natural e exibe o conflito com o neto que sente ciúmes e fica revoltado com outra paixão na vida da avó. Para o neto compreender o romance entre Belinha e Seu Manu, a avó conta sua história de amor com o falecido avô, que vem acompanhada da história do menino Lúcio. Nesse momento, o narrador Lúcio se recolhe para dar voz à narrativa da avó e passa para o papel de ouvinte:

- Lúcio, eu e seu avô formávamos um casal muito animado e feliz. Tudo era junto: dançar, viajar, jogar boliche, pingue-pongue... [...] Nós éramos grandes companheiros. [...] Em compensação, tivemos tantas alegrias que eu nunca reclamei. Foi um tempo de muita conversa e movimento. Ele me fazia correr nos parques, saltar, praticar muitos esportes... Seu avô morreu de repente. Era um atleta. Tão forte que eu nunca imaginei que isso pudesse acontecer. $\mathrm{O}$ mundo apagou. Todo o movimento parou a partir daquele instante. Eu adoeci de saudade, medo e solidão. Ficou um silêncio... Um silêncio muito grande. Silêncio que só foi quebrado quatro anos depois pelo seu choro (Zuca, 2010, p. 14)

A narrativa aponta para o aprendizado do amor em qualquer idade e a saída da solidão. A avó conta sua história para o neto e mostra que a chegada dele, quatro anos após a morte do marido, devolveu-lhe a alegria de viver:

Quando você nasceu uma luz acendeu dentro de mim outra vez. Aí eu vi que tinha uma missão importante na família. Você passou a ser a fonte das minhas atenções. Morre uma árvore e nasce uma semente. Foi fazendo as suas papinhas que eu voltei a cozinhar. Lembro quando fiz o primeiro pão caseiro dessa nova fase.

E agora, você já está com onze anos. É um rapaz. Já pode entender que o amor não tem idade e que ninguém deve ficar condenado à eterna solidão. Você será sempre o meu netinho querido. Se não fosse você, eu, talvez, ainda estivesse apagada (Zuca, 2010, p. 15).

O narrador finaliza com a sua nova história, pois se muda para a cidade grande junto com seus pais. A avó se casa com o padeiro e vão morar juntos. O pai foi transferido e ganhou um novo cargo, enquanto a mãe ficou sem emprego e passou a conversar mais com o filho, ocupando um pouco o lugar da avó. Mesmo à distância, o menino não se esquece da amada avó, o cheiro do pão evoca sua presença, e ele entra na internet para enviar-lhe uma mensagem.

Outra obra protagonizada por uma criança que revela uma relação intensa entre duas gerações diferentes é Vovô é um Cometa, de Ricardo Filho (2008). É narrada em primeira pessoa por uma menina chamada Laura, a Laluzinha, que ama jogar futebol e compartilhar a vida cotidiana com seu avô Américo. Como se pode ver na apresentação do avô Américo, que na verdade é trisavô da menina, não há choque de

Educação \& Realidade, Porto Alegre, v. 38, n. 4, p. 1089-1112, out./dez. 2013. 1103 Disponível em: <http://www.ufrgs.br/edu_realidade> 
gerações; muito pelo contrário, valoriza-se o velho como a pessoa mais sábia da família:

\begin{abstract}
Deixa eu apresentar o meu avô para vocês. Na realidade ele é motivo de orgulho para mim. Não conheço ninguém que tenha um trisavô. [...] Meu pai comentou que devem existir poucas fotografias com cinco gerações. Quando eu não entendi, e pedi explicação, adivinha quem me socorreu, sempre com aquele jeito paciente? Ele, claro, meu vô Américo. Talvez por já ter vivido mais de cem anos, vai fazer cento e dois, seja o mais sábio da família. De um jeito claro e simples, falou que eu era uma geração, meu pai outra, meu avô, a bivó e ele próprio, cada um mais uma. Era só contar, dava cinco certinho (Filho, 2008, p. 7).
\end{abstract}

Laura cursa o quarto ano e gosta muito de jogar futebol; ela adora conversar todos os dias com seu trisavô Américo. Ele tem 102 anos e se lembra da penúltima passagem do cometa Halley em 1910, quando tinha 5 anos. A memória desse acontecimento é trazida à tona quando Laura fica sabendo da existência desse cometa na aula da professora Márcia, mas não consegue concentrar sua atenção por causa da final do campeonato de futebol. Então, ela pede para o avô contar essa história. Por meio das lembranças de Américo, Laura fica sabendo do alvoroço causado pela aproximação do cometa no início do século XX, e acaba conhecendo um pouco da história de São Paulo nesse período.

Ressalta-se que a relação entre avó e neta é intensa, de amor, partilha, cumplicidade e muitas aprendizagens. No caso do cometa, o aprendizado se dá com a escuta do idoso e não com a professora. Nas conversas entabuladas entre ambos, fica nítida uma coeducação de gerações. No decorrer da narrativa, o avô incentiva a neta no futebol e usa a gíria falada pela geração atual - cabeça superjovem:

Cheguei em casa feliz da vida, almocei bem depressa e fui para casa do vovô Américo, ali perto, na mesma rua. Eu sempre passo lá à tarde, para assinar o ponto, como ele diz.

Encontrei-o no quarto, de pijama e na cadeira de balanço. Dificilmente ele sai, preferindo roupas confortáveis.

[...]

- Tudo, fomos para a final do campeonato.

- Que supimpa!

Ele é assim. Às vezes usa umas palavras que ninguém usa. Sempre me incentivando com as minhas atividades, até mesmo o futebol. Talvez por isso tenha cento e dois anos sem ter ficado velho. A cabeça dele é superjovem (Filho, 2008, p. 13).

No capítulo V ele explica sobre os cometas e no final deixa a menina curiosa para saber sobre o cometa Halley. No capítulo VI, ele lembra o episódio do fim do mundo em 1910, quando tinha cinco anos, e mostra como a cidade de São Paulo e as coisas eram bem diferentes de hoje.

1104 Educação \& Realidade, Porto Alegre, v. 38, n. 4, p. 1089-1112, out./dez. 2013. Disponível em: <http://www.ufrgs.br/edu_realidade> 
Faz pausa para o lanche e deixa para contar do cometa no dia seguinte. No capítulo VII Laluzinha sonha com o cometa Halley, vai para escola sem prestar atenção na aula, depois chega na casa do avô com a maior expectativa de ouvir a história e ele faz mais suspense, aumentando ainda mais sua expectativa: "Mais uma vez ele ficou naquele joguinho que já estava ficando insuportável. Acho que faz de propósito, para dar mais colorido ao que conta. Ninguém sabe inventar uma história tão bem [...]" (Filho, 2008, p. 25).

Uma relação marcada pelo amor mútuo, pelas trocas de experiências cotidianas, em que o convívio com a neta traz alegria, forças e esperanças na vida do avô, mas a recíproca também é verdadeira - ambos aprendem e se fortalecem juntos:

\begin{abstract}
Uma das coisas que ainda não expliquei e acho supergostosa é o jeito como o vovô me recebe. Faz questão de mostrar que fica feliz com minhas visitas. Acabo me sentindo a pessoa mais importante do mundo, o carinho dele é uma delícia. Tenho certeza que esse amor que a gente tem um pelo outro me ajuda muito. Não entendo direito por que, mas me sinto mais forte por causa dele. Outro dia, num jogo de futebol, quando a gente estava perdendo, eu pensei nele, lembrei que era sua trineta preferida e me senti capaz de virar aquela partida. E não deu outra: acabamos ganhando (Filho, 2008, p. 31).
\end{abstract}

As limitações fazem parte do cotidiano do idoso como, por exemplo, o cansaço na fala; no entanto, o respeito pelo tempo do avô e a ausência de pressa da neta mostram um relacionamento que supera o ritmo acelerado imposto pelas sociedades de consumo, onde a pressa das pessoas não deixa espaço para conversas: "Vô Américo estava muito bem-disposto. Não parecia que ia se cansar de falar naquele dia. Como eu não tinha pressa, fui ficando por ali, cada vez mais interessada" (Filho, 2008, p. 34).

O final da história mostra os sonhos que a menina tem para o futuro, incluindo o desejo de o avô continuar vivo e compartilhando a vida com ela: “[...] Vovô Américo tinha virado um cometa e me convidava pra assistir à próxima passagem do Halley, em 2061. Garantiu-me que estaria vivo. Não duvidei já que meu avô é, sem dúvida, um fenômeno" (Filho, 2008, p. 39).

\title{
Velhice, Sabedoria, Partilhas e Aprendizagens em Outras Culturas
}

É isto que eu quero neste pequeno livro: partilhar um pouco de minha história, da história do meu povo e do meu avô ancestral que me levou a compreender a sabedoria que está em todas as coisas e me fez descobrir que não nascemos para estar o tempo todo no chão. Nascemos

Educação \& Realidade, Porto Alegre, v. 38, n. 4, p. 1089-1112, out./dez. 2013.1105 Disponível em: <http://www.ufrgs.br/edu_realidade> 
com asas para voar em muitas direções, às vezes sem sair do lugar (Munduruku, 2009, p. 7).

Em obras infantis que tematizam as culturas dos povos africanos, a figura do velho como o mais sábio, aquele que aconselha e conta histórias é recorrente tendo em vista a força da oralidade nessas sociedades. É o caso de As Tranças de Bintou, de Sylviane A. Diouf (2004), narrada pela voz de uma criança - a menina Bintou. Essa obra permite conhecer os costumes africanos por meio da história de uma menina negra que sonha em usar tranças porque acha que seu cabelo curto e crespo é "bobo e sem graça” (Diouf, 2004, p. 2) por ter apenas quatro birotes na cabeça.

Para resolver seu conflito, a narradora protagonista recorre à voz da experiência, sua avó, que responde à indagação da neta por meio de uma história:

Vovó Soukeye sabe de tudo. É o que mamãe sempre diz. Ela me explicou que os mais velhos sabem mais porque viveram mais, e por isso aprenderam mais. E, já que a vovó sabe tudo, eu lhe pergunto por que as meninas não podem usar tranças.

"Há muito tempo, existiu uma menina vaidosa e egoísta. Foi nessa época, e por isso, que as mães decidiram que as crianças não usariam tranças, só birotes, porque elas ficariam mais interessadas em fazer amigos, brincar e aprender".

Vovó me acaricia e diz: "Querida Bintou, quando for mais velha, você terá bastante tempo para a vaidade e para mostrar a todos a bela mulher que você será. Mas, agora, querida, você é apenas uma criança. Poderá usar tranças no momento adequado" (Diouf, 2004, p. 10).

No final da narrativa, a avó é a responsável por solucionar o conflito vivenciado pela neta, que deseja usar a trança antes de chegar o momento na cultura do seu povo. Vovó Soukeye faz a menina sentir-se muito especial, deixando seu cabelo tão especial quanto ela, ao fazer os birotes com adereços infantis e auxiliando a menina a assumir sua identidade negra e infantil:

Vovó pede: "Abra seus olhos, querida Bintou". É quando vejo pássaros amarelos e azuis em meu cabelo. Foi-se a menina sem graça com quatro birotes na cabeça. No espelho, aparece uma garota com um lindo cabelo olhando para mim (Diouf, 2004, p. 28).

Eu sou Bintou. Meu cabelo é negro e brilhante. Meu cabelo é macio e bonito. Eu sou a menina dos pássaros no cabelo. O sol me segue e estou muito feliz (Diouf, 2004, p. 29).

Outra obra infantil traduzida, que aborda a convivência entre avó e neta de etnia havaiana, é Bonita, é Assim que Vovó me Chama, de Bar-

1106 Educação \& Realidade, Porto Alegre, v. 38, n. 4, p. 1089-1112, out./dez. 2013. Disponível em: <http://www.ufrgs.br/edu_realidade> 
bara M. Joosse (2009), cuja narrativa é pautada no diálogo entre a neta e sua avó, equilibrando as vozes de uma maneira poética e harmônica.

Trata-se de uma história delicada que revela o amor eterno e incondicional da avó pela neta. As personagens vovó e Bonita são nativas do Havaí, apresentando um modo de vida predominantemente moderno, mas que convive com o tradicional. Vovó conta a história de Bonita para dizer o quanto a menina é especial e para rememorar as tradições de seus ancestrais e da ilha. Ressalta-se que a história oral é tecida no barbante:

- Ei!, Tutu, conta a nossa história. - Bonita foi se encolhendo até ficar do tamanho de um broto de kalo, e se aconchegou nos braços da vovó.

- Uma história? Mas existem tantas... Qual devo escolher? - Você sabe, Tutu! Nossa história. Aquela Bonita.

Vovó pegou um barbante e começou... (Joosse, 2009, p. 5).

Enquanto vovó tecia o restante da história oral, os dedos de \Bonita iam se entrelaçando (Joosse, 2009, p. 10).

A sabedoria da avó é manifesta na experiência do contar e no reconhecimento da beleza da alteridade, no olhar sensível para a diversidade de cores presentes na natureza e na valorização étnica do povo havaiano:

Quando terminou de contar a história, vovó escondeu o barbante.

- Tutu - disse Bonita -, as galinhas têm penas de cores tão variadas!

- Ae! E têm orgulho de suas cores.

- E os porquinhos, as libélulas e os passarinhos! Até mesmo os caracóis terrestres parecem jóias nas árvores.

- Sim, eles gostam de suas cores (Joosse, 2009, p. 15).

- Mas meu cabelo é pretinho.

- Preta é a cor da noite profunda e escura, onde as estrelas faíscam.

- E minha pele é marrom.

- Marrom é a cor do campo de kalo, que muitos pés amaciaram. (Joosse, 2009, p. 17).

- Bonita, para sempre e eternamente Bonita (Joosse, 2009, p. 31).

Além da cultura africana e havaiana, a figura do idoso como uma pessoa sábia também está presente na cultura dos povos indígenas. Em Meu Vô Apolinário, Daniel Munduruku (2009) compartilha sua história, a história de seu povo e a do seu avô ancestral, cuja convivência - de acordo com suas palavras na introdução -, ainda que pouca, marcou profundamente sua vida e o fez resgatar a história de seu povo e a aceitar a sua condição de ser índio. Nessa história, o narrador busca na memória suas raízes ancestrais e partilha com o leitor os ensinamentos de seu avô, abordando temas fundamentais para nossa humanização:

Educação \& Realidade, Porto Alegre, v. 38, n. 4, p. 1089-1112, out./dez. 2013. 1107 Disponível em: <http://www.ufrgs.br/edu_realidade> 
a construção da identidade, a busca da autoestima, o conflito entre as diferenças culturais, a diversidade de pontos de vista e a relação entre homem e natureza.

A poesia da sabedoria dos anciãos indígenas é experimentada nas histórias contadas pelos velhos e pelas velhas da aldeia:

A primeira lembrança que carrego comigo é da escuridão da noite. As noites eram muito escuras, e toda iluminação era feita pelas fogueiras acesas em frente das casas e pelas poucas lamparinas a querosene, uma inovação para nós. A gente se sentava diante das casas dos parentes e ficava horas a ouvir histórias contadas pelos velhos e velhas da aldeia. Algumas histórias eram horripilantes e davam medo de ouvir. Elas falavam dos seres da floresta que gostam de brincar com os humanos. Essas criaturas apareciam de vez em quando para amedrontar as criancinhas. Era o saci-pererê, a matintaperera, o curupira, o boitatá, entre outros. Nossas anciãs contavam a história de forma tão encantada que pareciam verdadeiras e todos morriam de medo, tanto que, muitas vezes, a gente não tinha coragem nem mesmo de levantar para ir embora. Nossa fantasia era alimentada e visitada por esses pequenos seres - verdadeiros - trazidos até nós pela voz cantilena de nossas avós (Munduruku, 2009, p. 13-14).

Ao resgatar a figura do avô Apolinário, o narrador expõe sua força física para um homem com mais de oitenta anos e também realça seus saberes e fazeres em prol da comunidade indígena:

[...] As pessoas, eu via, sempre se aproximavam dele a fim de falar, pedir conselhos ou para que ele receitasse alguma erva para a cura de doenças. [...] Quando a pessoa acabava de dizer tudo o que queria, ele se levantava, ia até o quintal de sua casa e trazia nas mãos algumas folhas e as entregava ao doente explicando o que deveria fazer para se curar.

Outras vezes - quando o assunto parecia ser sério -, ele mesmo operava a cura do paciente. Fazia a pessoa deitarse ou sentar-se dentro de sua maloca, pegava uns ramos de folhas, incensava-os com seu cigarro de palha, molhava-os em água nova e então os jogava pelo corpo do paciente enquanto recitava uma prece numa língua, pelo menos parecia a mim, estranha. Também usava o maracá e penas de mutum. O doente sempre se curava e trazia, como pagamento, algum produto por ele cultivado (Munduruku, 2009, p. 27).

Com se vê, o saber extraído da experiência do mais velho colabora nas lutas e na resolução dos problemas da aldeia. Também auxilia o neto, imerso nos problemas e contradições do tempo presente, a aceitar sua condição de ser índio e a buscar sua identidade e sua autoestima. O avô ensina o menino a aprender com o rio:

1108 Educação \& Realidade, Porto Alegre, v. 38, n. 4, p. 1089-1112, out./dez. 2013 Disponível em: <http://www.ufrgs.br/edu_realidade> 
- [...] Sei que está assim porque as pessoas o julgam inferior a elas e seus pais não o ajudam muito a compreender tudo isso. Pois bem. Já é hora de saber algumas verdades sobre quem você é. Por isso eu o trouxe aqui. Você viu o rio, olhou para as águas. O que lhe ensinaram? A paciência e a perseverança. Paciência de seguir o próprio caminho de forma constante, sem nunca apressar seu curso; perseverança para ultrapassar todos os obstáculos que surgirem no caminho. Ele sabe aonde quer chegar e sabe que vai chegar, não importa o que tenha de fazer para isso. Ele sabe que o destino dele é unir-se ao grande rio Tapajós, dono de todos os rios. Temos de ser como o rio, meu neto. Temos de ter paciência e coragem. Caminhar lentamente, mas sem parar. Temos de acreditar que somos parte deste rio e que nossa vida vai se juntar a ele quando já tivermos partido desta vida. Temos de acreditar que somos apenas um fio na grande teia da vida, mas um fio importante, sem o qual a teia desmorona. Quando você estiver com esses pensamentos outra vez, venha para cá ouvir o rio (Munduruku, 2009, p. 30-31).

O narrador Apolinário conta aquilo que aprendeu com a sua própria experiência na aldeia, e esse aprendizado ele transforma em experiência para seu neto, que ouve a sua história (Benjamin, 1987). A partir desses ensinamentos, o menino índio transforma seu modo de viver e de pensar em comunhão com a natureza. O saber narrado pelo idoso, que nunca saiu da aldeia, e escutado atentamente pelo neto cria vínculos afetivos entre ambos, tornando possível uma relação igualitária por meio do diálogo, do conhecimento e da cumplicidade:

Acho que esse foi o maior discurso que ouvi de meu avô. Depois disso, conversamos muitas vezes. Sempre sobre coisas maravilhosas. Nasceu entre nós uma cumplicidade muito grande e ele foi me conduzindo por um caminho de conhecimento que nunca imaginei possível ter fora da cidade. O mais impressionante é que o velho Apolinário não conhecia nada da cidade de Belém ou de nenhuma outra. Nunca soube que ele tivesse viajado para outros lugares. Meu pai depois confirmou que, de fato, meu avô nunca havia saído da aldeia (Munduruku, 2009, p. 31).

Os conhecimentos são compartilhados. O legado do mais velho a sabedoria - é deixado como experiência para o mais novo e o ancião considera que sua missão já está cumprida. O avô morre quando o neto consegue se aceitar e construir sua identidade de índio, alçando voo e continuando o saber compreendido no mundo ancestral de seu avô:

- Então a minha hora já chegou. Preciso meu unir ao Grande Rio. Lembre sempre, porém, que só existem duas coisas importantes para saber na vida: 1) Nunca se preocupe com coisas pequenas; 2) Todas as coisas são pequenas.

Educação \& Realidade, Porto Alegre, v. 38, n. 4, p. 1089-1112, out./dez. 2013. 
[...] Nunca tomei decisões sem antes ouvir os enviados alados e escutar o que eles têm a me dizer, conforme meu avô me pediu. Ele, que foi meu (a)vô(o) para minha compreensão e ancestralidade. Esta história mesma nasceu de um sonho.

Já enfrento o mundo com mais serenidade e nunca me esqueço de colocar os pés no chão, na água, nem de sentir o vento batendo em meu rosto trazendo notícias de longe. Não tenho pressa de chegar, pois sei esperar e ouvir e perseverar; sei também que, como o rio, irei chegar aonde quero (Munduruku, 2009, p. 37).

Observa-se a temática da velhice presente juntamente com a da morte, indicando o curso natural da vida. $\mathrm{O}$ envelhecimento, que termina com a morte, faz parte da condição humana. A literatura infantil avança nessas questões por muito tempo consideradas inadequadas para as crianças, afastando a infância de sua outra ponta com o intuito de poupá-la, mas que fazem parte de nossa existência e, por isso, são temas relevantes para todas as idades.

\section{Tecendo Alguns Fios e Cosendo os Pedaços das Histórias}

Os fios tecidos nas narrativas revelam que o elo entre as gerações não pode ser rompido; a experiência dos mais velhos precisa ser valorizada pelo resgate de suas lembranças e histórias que falam da vida, recuperando uma memória pessoal que é também coletiva. Como visto nas sábias reflexões de Ecléa Bosi (1987) e de Simone de Beauvoir (1976), os velhos servem para lembrar.

As obras literárias estudadas dão vozes aos velhos e confirmam que a função social do idoso é, sobretudo, lembrar e contar histórias. Nas relações estabelecidas entre as personagens avós e netos, as vidas são compartilhadas por meio das narrativas orais, das brincadeiras, do afeto e da cumplicidade. Não se pode esquecer que os retalhos das lembranças individuais, ao serem cosidos, reconstroem uma colcha (ou manta) que recupera uma memória coletiva. Por isso, velhos contam, lembram e aconselham, extraindo forças criadoras para continuarem a existir. Mas é preciso que alguém os ouça. Na outra ponta etária estão as crianças que ainda não foram absorvidas completamente pela cultura de massas e escutam as histórias dos velhos, recriando práticas culturais ancestrais. Compartilhando suas vidas, avós e netos reinventam a existência em conjunto, transformando-se mutuamente. As representações de avós e netos na literatura infantil convergem com a pesquisa realizada pelo sociólogo Paulo de Salles Oliveira (1999), que encontra relações igualitárias de convivência no encontro entre sujeitos sociais diferentes. Para ele, por esses grupos etários serem inferiorizados socialmente, são capazes de criar conjuntamente outras práticas de convivência e reinventar suas vidas com partilhas e resistência as práticas opressoras.

1110 Educação \& Realidade, Porto Alegre, v. 38, n. 4, p. 1089-1112, out./dez. 2013. Disponível em: <http://www.ufrgs.br/edu_realidade> 
Convém destacar que muitas narrativas resgatam a figura do narrador (Benjamin, 1987), daquele que não se esqueceu, daquele que tem o que dizer porque viveu a trabalhar e, assim, a imprimir a marca intransferível do seu fazer. A sabedoria dos avós compartilhada com os netos transforma a vida de ambos numa grande aventura.

De modo geral, as dez obras analisadas apresentam representações da velhice de forma positiva ao resgatarem a figura do velho como o contador de histórias vivenciadas ou inventadas, valorizando a velhice como fonte de sabedoria para as crianças. Com isso, as narrativas trazem significativas contribuições que apontam para o reconhecimento e o respeito pela alteridade, assim como possibilitam um novo aprendizado sobre a coeducação de gerações na vida cotidiana, permeada pela afetividade, pela igualdade e pela partilha de histórias e saberes entre avós e netos.

Para finalizar, este estudo mostra que, diferente da sociedade capitalista que só considera a produção, os rendimentos dos sujeitos e, por isso, marginaliza o velho que não oferece mais lucros, a criança representada nas obras infantis escuta o velho e aprende com suas histórias e experiências, valorizando e respeitando o velho enquanto ser humano, que experimenta um cotidiano por vezes tão penoso. Entre os dois, criase uma relação simétrica que aponta para uma transformação radical na vida.

Recebido em 26 de março de 2013 Aprovado em 18 de agosto de 2013

\section{Referências}

ALBERGARIA, Lino de. Álbum de Família. Ilust. Ana Maria Moura. São Paulo: Edições SM, 2005. (Muriqui Júnior).

BEAUVOIR, Simone de. A Velhice: a realidade incômoda. Trad. Heloysa de Lima Dantas. São Paulo: Difel, 1976. V. I.

BENJAMIN, Walter. O Narrador. In: BENJAMIN, Walter. Obras Escolhidas I. Trad. P. S. Rouanet. 3. ed. São Paulo: Brasiliense, 1987.

BOSI, Ecléa. Memória e Sociedade: lembrança de velhos. 2. ed. São Paulo: T. A. Queiroz: Editora da Universidade de São Paulo, 1987.

COELHO, Nelly Novaes. Panorama Histórico da Literatura Infantil/Juvenil. 4. ed. rev. São Paulo: Ática, 1991.

DELÁCIO, Célia Regina. Os Idosos e o Tempo Útil de Trabalho. Marília: UNESP/ Faculdade de Filosofia e Ciências, 1988. (Séries Monográficas. Iniciação Científica; 1$)$.

DIOUF, Sylviane A. As Tranças de Bintou. Ilust. Shane W. Evans. Trad. Charles Cosac. São Paulo: Cosac \& Naify, 2004.

FILHO, Ricardo. Vovô É Um Cometa. Ilust. Ângelo Abu. Curitiba: Positivo, 2008. (Coleção Tempo-Rei).

JOOSSE, Barbara M. Bonita, É Assim que Vovó Me Chama. Ilust. Barbara Lavalle. Trad. José Feres Sabino. São Paulo: Brinque-Book, 2009.

Educação \& Realidade, Porto Alegre, v. 38, n. 4, p. 1089-1112, out./dez. 2013.1111 Disponível em: <http://www.ufrgs.br/edu_realidade> 
LAJOLO, Marisa; ZILBERMAN, Regina. A Formação da Leitura no Brasil. 2. ed. São Paulo: Ática, 1998.

LAJOLO, Marisa; ZILBERMAN, Regina. Um Brasil Para Crianças: para conhecer a literatura infantil brasileira: histórias, autores e textos. São Paulo: Global, 1986.

MARTHA, Alice Áurea Penteado. O tempo, de óculos, requebra numa bengala: Sylvia Orthof e a velhice. In: CECCANTINI, João Luís C. T. Leitura e Literatura Infanto-Juvenil: memória de Gramado. São Paulo: Cultura Acadêmica; Assis, SP: ANEP, 2004. P. 84-97.

MARTINS, Isabel Minhós. A Manta: uma história em quadrinhos (de tecido). Ilust. Yara Kono. São Paulo: Tordesilhinhas, 2011.

MEIRELES, Cecília. Problemas da Literatura Infantil. 2. ed. São Paulo: Summus, 1979. (Novas Buscas em Educação; v. 3).

MUNDURUKU, Daniel. Meu Vô Apolinário. Ilust. Rogério Borges. 2.ed. São Paulo: Studio Nobel, 2009.

MURRAY, Roseana. Um Avô e Seu Neto. Ilust. Eduardo Albini. São Paulo: Moderna, 2000.

OLIVEIRA, Paulo de Salles. Prefácio. In: DELÁCIO, Célia Regina. Os Idosos e o Tempo Útil de Trabalho. Marília, SP: UNESP/ Faculdade de Filosofia e Ciências, 1988. (Séries Monográficas. Iniciação Científica, 1). P. 4-5.

OLIVEIRA, Paulo de Salles. Vidas Compartilhadas: cultura e coeducação de gerações na vida cotidiana. São Paulo: Hucitec/FAPESP, 1999.

QUEIROZ, Magali. Casa de Vó é Gostoso que Só. Ilust. Vera Muccillo. Florianópolis: Cuca Fresca, 2010.

SILVA, Conceil Corrêa da; RIBEIRO, Nye. A Colcha de Retalhos. Ilust. Ellen Pestili. 2. ed. São Paulo. Editora do Brasil, 2010. (Coleção Viagens do Coração).

ZILBERMAN, Regina. Como e Por Que Ler a Literatura Infantil Brasileira. Rio de Janeiro: Objetiva, 2005.

ZUCA, Zé. Avó Com Cheiro de Pão Caseiro: uma história de sabores e lembranças. Ilust. Marilia Pirillo. Rio de Janeiro: Zit, 2010.

Célia Regina Delácio Fernandes é doutora em Teoria e História Literária pelo IEL/UNICAMP (2004). Professora da Universidade Federal da Grande Dourados - UFGD, onde desenvolve atividades de ensino, pesquisa e extensão na Graduação e Pós-Graduação em Letras, nas áreas de leitura, literatura e ensino, literatura infantojuvenil e políticas públicas de leitura. Coordenadora e pesquisadora do Centro de Estudos em Ensino, Leitura, Literatura e Escrita - CEELLE/UFGD. Também é coordenadora do PROLer - Comitê de Dourados-MS

E-mail: celiafernandes@ufgd.edu.br

1112 Educação \& Realidade, Porto Alegre, v. 38, n. 4, p. 1089-1112, out./dez. 2013. Disponível em: <http://www.ufrgs.br/edu_realidade> 